\title{
UJI FASTENING PADA KAYU KOMPOSIT SERAT PANDAN WANGI DAN LIMBAH KAYU DENGAN RESIN POLYESTER
}

\author{
Emmy Dyah S. ${ }^{1)}$, Nasmi H.S. ${ }^{2)}$, Sinarep ${ }^{3)}$, Pandri Pandiatmi ${ }^{4}$, Insan Andrian ${ }^{5)}$ \\ 1,2,3,4,5 Jurusan Teknik Mesin, Fakultas Teknik, Universitas Mataram \\ E-Mail: Emmydyahsulistyowati@rocketmail.com
}

\begin{abstract}
Abstraksi
Tujuan dari penelitian ini adalah untuk mendapatkan jenis penanganan penyambungan pada pemakaian sebagai panel pintu, lembaran atap, dinding dan lantai. Untuk itu pengujian yang dilakukan adalah uji fastening. Teknik pembuatan papan komposit dilakukan dengan menggunakan teknik hand lay up. Material penyusun papan komposit adalah serat pandan wangi dengan variasi panjang serat $15 \mathrm{~mm}, 20 \mathrm{~mm}$, dan $30 \mathrm{~mm}$ dan fraksi volume serat $20 \%$ dan $30 \%$ sedangkan untuk filler serbuk kayu sengon $5 \%$. Perekat yang digunakan adalah resin polyester. Hasil keluaran dari penelitian dimana predrilling pada ukuran fastener \#6, \#8 dan \#10 sebesar $3,5 \mathrm{~mm}, 4 \mathrm{~mm}$ dan $4,5 \mathrm{~mm}$, sedangkan antara jarak fastener didapatkan jarak masing-masing fastener tergantung pada kepala fastener itu sendiri yaitu fastener \#6, \#8, dan \#10, adapun pada jarak kritis fastener antar tepi panjang dan fraksi volume serat pandan wangi berpengaruh nyata dapat dilihat nilai tertinggi pada panjang serat $15 \mathrm{~mm}$ dan fraksi volume 20 $\%$ sebesar $3,29 \mathrm{~mm}$, dan nilai terendah terdapat pada panjang serat $15 \mathrm{~mm}$ dan fraksi volume $30 \%$ sebesar $2,74 \mathrm{~mm}$.
\end{abstract}

\begin{abstract}
The purpose of this study was to obtain handling connection type in use as door panels, roofing sheets, walls and floors. Therefore, the tests performed are fastening test and abrasion test. The technique of making wood composite is using hand lay-up technique. Constituent material of board composite is using pandanwangifibers with length variationsare $15 \mathrm{~mm}, 20$ $\mathrm{mm}$, and $30 \mathrm{~mm}$ with volume fraction variations are $20 \%$ and $30 \%$, and $5 \%$ Sengon tree sawdust is used as the filler. The results showed that pre-drilling with fastener sizes \# 6, \# 8 and \# 10 is $3.5 \mathrm{~mm}, 4 \mathrm{~mm}$ and $4,5 \mathrm{~mm}$. The distance between each fastener depends on the fastener head itself, ie fastener \# 6, \# 8, and \# 10. Critical distance between the edge of the fastener has a significant effect on fiber length and volume fraction. The highest value is shown on $15 \mathrm{~mm}$ of the fiber length and $20 \%$ of volume fraction with the value $3.29 \mathrm{~mm}$, and the lowest value is shown on $15 \mathrm{~mm}$ of the fiber length and $30 \%$ of volume fraction with the value $2.74 \mathrm{~mm}$.
\end{abstract}

Key words : board composite, pandanwangi fiber, fastening, polyester and saw-dust

\section{PENDAHULUAN}

Saat ini ilmu pengetahuan dan teknologi dalam bidang rekayasa material serta berkembangnya isu lingkungan hidup menuntut terobosan baru dalam menciptakan material-material yang berkualitas tinggi serta ramah lingkungan. Pemakaian akhir material logam dan keramik akan menyisakan residu di alam, karena material tersebut sulit dihancurkan oleh alam dalam waktu singkat. Oleh karena itu, pemakaian material ramah lingkungan, mampu didaur ulang serta mampu dihancurkan sendiri oleh alam merupakan tuntutan teknologi saat ini[1]. Komposit juga merupakan salah satu jenis material di dalam dunia teknik yang dibuat dengan penggabungan dua macam bahan yang mempunyai sifat berbeda menjadi satu material baru dengan sifat yang berbeda pula. Penelitian yang mengarah pada perkembangan bahan komposit telah banyak dilakukan, terutama yang berkaitan dengan komposit penguatan serat alam yang berbahan matrik polimer. Penelitian ini dilakukan seiring dengan majunya penggunaan bahan alami dalam kehidupan sehari-hari. Kelebihan mendasar yang dimiliki oleh serat alam adalah jumlahnya berlimpah, memiliki biaya produksi yang rendah, dapat diperbarui dan didaur ulang, serta tidak mencemari lingkungan.

Serat alam sekarang banyak digunakan karena jumlahnya banyak dan 
sangat murah jadi sering dimanfaatkan sebagai material penguat seperti serat pandan wangi Pandanus amaryllifoliu, Roxb, kenaf, abaca, rosella, jerami dan masih banyak serat alam yang lain yang bisa dimanfaatkan, akan tetapi serat alam mempunyai kekuatan yang rendah dibandingkan serat buatan.

Berbagai macam pengujian pun sudah dilakukan pada komposit serat daun pandan untuk memperoleh sifat mekanik yang tinggi salah satunnya seperti uji bending, didapat kekuatan bending yang paling rendah pada specimen dengan menggunakan serat pandan wangi pada fraksi volume serat $20 \%$ sebesar 171,76 KN dan kekuatan paling tinggi didapat pada fraksi volume serat $40 \%$ sebesar 236,67 [2].

Adapun penelitian dalam metode fastening komposit sandwich polyester diperkuat serat tumbuhan-limbah industri dengan honeycomb core dari kertas bekas dimana komposisi penyusun kulit komposit mempengaruhi jarak kritis akhir fastener dari komposit sandwich dengan menggunakan abu sekam sebagai filler, untuk alat ukur fastener \#6, \#8, \#10 adalah 6,3 mm, 6,7 mm, $7,7 \mathrm{~mm}$ [3].

Tujuan dari penelitian ini untuk mengetahui pengaruh panjang dan fraksi volume serat terhadap uji fastening dan abrasion pada papan komposit serat pandan wangi dan limbah kayu dengan resin polyester yang mempunyai ketahanan terhadap penetrasi sekrup dan keausan.

\section{LANDASAN TEORI Tinjauan Pustaka}

Beberapa penelitian mengembangkan produk komposit plastik dengan penguat serat tumbuhan untuk beberapa aplikasi konstruksi seperti bahan atap, plafon, panelpanel, keset, dan bahan bangunan lain dengan biaya yang rendah. Pada studi mengenai komposit partikel-polimer dengan penguat serat tumbuhan jute, filler flyash, dan resin epoxy, menunjukkan bahwa komposit ini merupakan material potensial yang memberi sifat fisik dan mekanik yang unggul. Juga dilaporkan bahwa serat tumbuhan untuk menggantikan serat sintetis pada komposit polimer mampu mengurangi biaya bahan. Alasan yang lain adalah karena serat alam mempunyai modulus yang baik dan berat jenis yang rendah [4].

Selain temuan bahan komposit diatas, temuan lain komposit partikel-polimer dari bahan limbah kayu, dan serat alam yang menjadi perhatian utama di Laboratorium
Bahan Jurusan Teknik Mesin, Universitas Mataram dan telah menghasilkan beberapa temuan. Seperti misalnya; pemakaian limbah serbuk kayu 5\% pada komposit diperkuat serat pandan wangi menghasilkan kekuatan bending dan ketangguhan impact yang tinggi.

\section{Material Komposit}

Kata komposit memberikan suatu pengertian yang sangat luas dan berbeda beda mengikuti situasi dan perkembangan bahan itu sendiri. Gabungan dua atau lebih bahan merupakan suatu konsep yang diperkenalkan untuk menerangkan definisi komposit.

Komposit dibentuk dari dua jenis material utama yaitu penguat (reinforcement) dan matriks sebagai pengikat. Keunggulan dari material komposit bila dibandingkan dengan material lainnya adalah penggabungan unsur - unsur pembentuknya tersebut. Sifat material hasil penggabungan ini diharapkan dapat saling melengkapi kelemahan-kelemahan yang ada pada masing-masing material penyusunnya. Dengan memilih kombinasi material penguat dan pengikat yang tepat, maka dapat dihasilkan suatu material komposit dengan sifat yang sesuai dengan keinginan. Material komposit memiliki beberapa keunggulan diantaranya bobot ringan, mempunyai kekuatan dan kekakuan yang baik, biaya produksi yang murah, tahan korosi dan lain lain.

\section{Pandan Wangi}

Tanaman pandan wangi terdapat kadang-kadang di pinggir sungai, di tepi rawa atau di tanah yang basah. Subur di daerah pantai sampai ketinggian 500 meter di atas permukaan laut. Batangnya bulat dengan bekas duduk daun, bisa bercabangcabang, menjalar, akar tunjang ke luar di sekitar pangkal batang dan cabang. Daun tunggal, duduk, dengan pangkal memeluk batang, tersusun berbaris tiga dalam garis spiral. Helai daun berbentuk pita, tipis, licin, ujung runcing, tepi rata. Bagi tanaman yang subur, daunnya bisa mencapai pajang antara 40 sampai $80 \mathrm{~cm}$, lebar 3 sampai 5 $\mathrm{cm}$, warna hijau, bila diremas berbau harum. Bunga majemuk, bongkol, putih. Buahnya batu, menggantung, bentuk bola, warna jingga. Memperbanyak tumbuhan pandan bisa dilakukan dengan memisahkan tunastunas muda yang tumbuh diantara akarakarnya 
Merupakan salah satu jenis kayu khas dari daerah tropis. Di Indonesia, kayu ini sangatlah familier dan banyak terdapat di Pulau Jawa. Sebab, di pulau ini pohon sengon banyak ditanam atau dibudidayakan oleh masyarakat baik secara individu maupun secara kelompok. Bahkan di kawasan ini, pengelolaannya dilakukan secara serius. Kayu sengon merupakan salah satu jenis kayu tropis yang memiliki nilai komersial yang sangat baik dalam pasar komoditas. Serbuk merupakan salah satu bentuk limbah industri penggergajian kayu dan belum banyak dimanfaatkan. Hasil penelitian pada beberapa industri penggergajian kayu di Sulawesi Selatan menunjukkan bahwa limbah yang dihasilkan rata-rata $52,56 \%$ dari bahan baku yang digunakan, termasuk di antaranya bentuk serbuk.

\section{Resin Polyester}

Merupakan jenis material polimer thermosetting, yaitu jenis material dimana terbentuknya ikatan dibantu oleh panas, katalis atau gabungannya. Matriks ini dapat menghasilkan keserasian matriks - penguat dengan mengontrol faktor jenis dan jumlah komponen, katalis, waktu, dan suhu. Sifatnya tahan creep, memadai selaku perekat struktur berbeban berat, serta tahan kondisi ekstrim panas, radiasi, kelembaban, dan tahan kimia.

\section{Pengujian Fastening}

Pengujian Fastening adalah uji dimana melakukan sambungan menggunakan fastener (pengikat) pada dua bahan menjadi satu, adapun jenis sambungan yaitu sambungan tetap dan sambungan tidak tetap. Pada sambungan tetap tidak mungkin untuk dibuka lagi tanpa merusak bahan contoh sambungan las, sambungan tidak tetap dimana pengikatnya dapat dibuka lagi tanpa merusak bahan yang disambung adapun contoh sambungan tidak tetap yaitu baut, sekrup, pasak paku keling. Pada penyambungan komposit sambungan harus mampu meneruskan gaya. Pemasangan fastener pada komposit harus tidak menyebabkan retaknya komposit. Papan komposit sesuai dengan standar spesimen batang uji yang standar spesimen ASTM D7332 / D7332M - 09[5].

\section{METODE PENELITIAN}

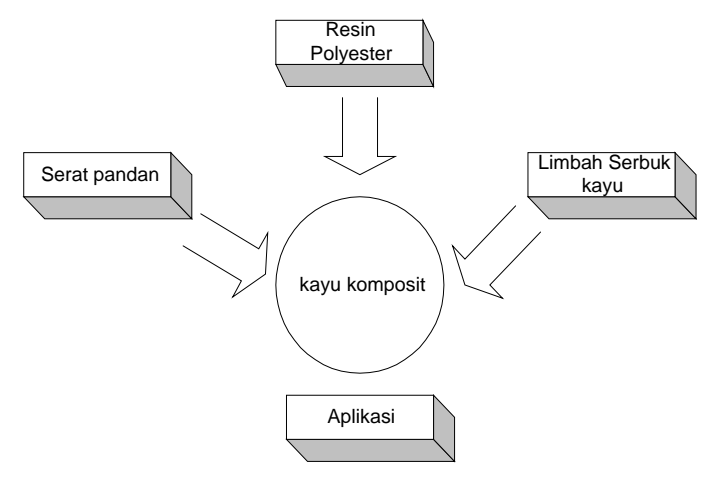

Gambar 1. Skema pemanfaatan serat alam dan limbah kayu. 


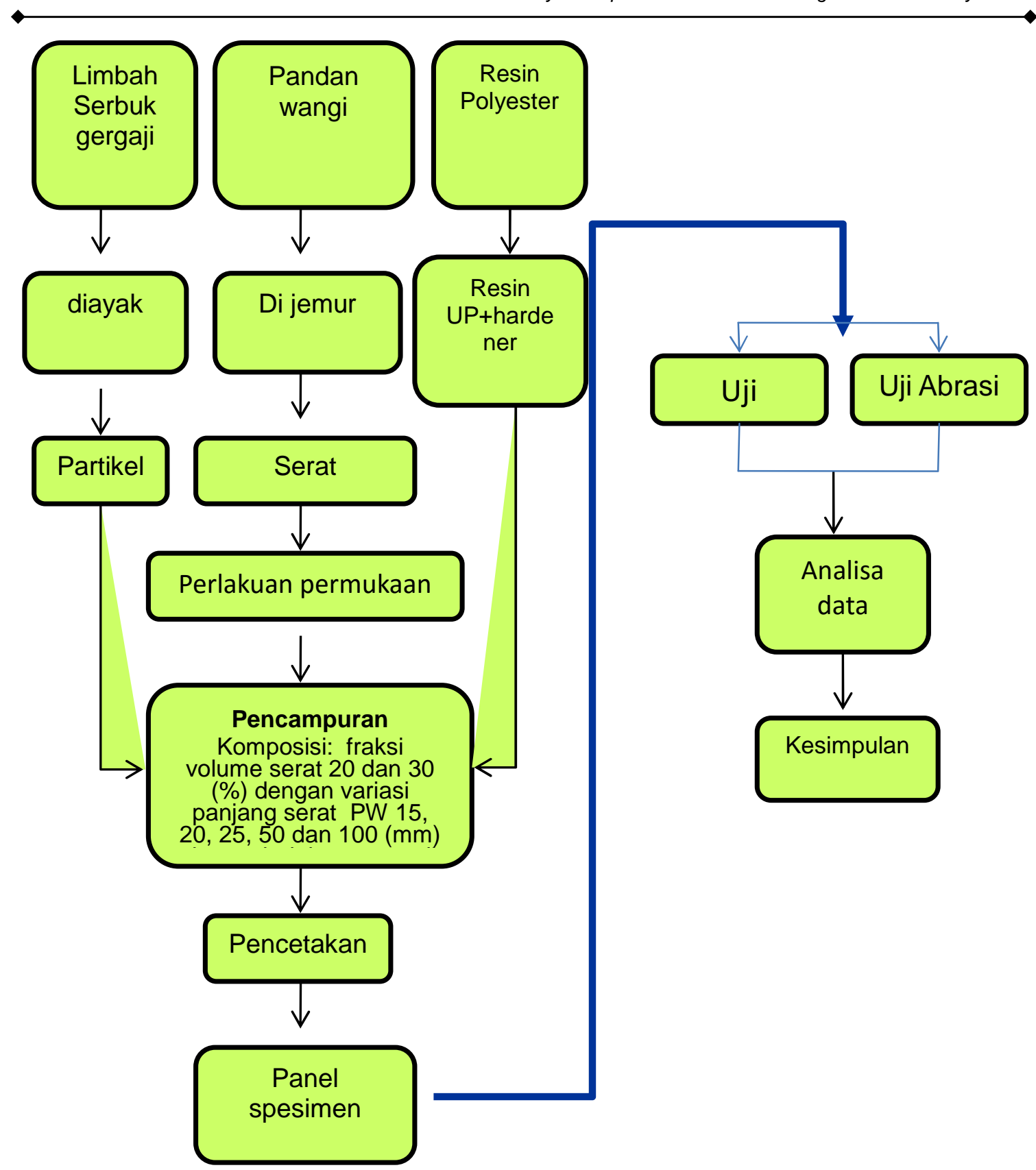

Gambar 2 Diagram alir penelitian.

\section{Pembuatan Spesimen}

a. Persiapan alat dan bahan

b. Pengolesan kit mobil pada cetakan untuk memudahkan pengambilan benda uji dari cetakan setelah mengalami proses pengeringan.

c. Penempatan masing-masing serat pandan dan serbuk kayu sengon ke dalam wadah pengaduk sesuai dengan komposisi.

d. Penuangan sebagian resin polyester dan katalis sesuai dengan komposisi ke dalam wadah pengaduk kemudian aduk hingga campuran resin, serat dan serbuk kayu merata selanjutnya tuang ke dalam masing-masing cetakan.

e. Penutup dengan kaca bagian atasnya yang bertujuan agar void yang kelihatan dapat diminimalkan jumlahnya yang kemudian dilakukan pengepresan dengan menggunakan alat penekan.

f. Proses pengeringan dibawah sinar matahari, proses ini dilakukan sampai benar-benar kering \pm 30 jam dan apabila masih belum benar-benar kering maka proses pengeringan dapat dilakukan lebih lama. 
g. Proses pengambilan komposit dari cetakan dapat menggunakan pisau ataupun cutter.

Komposit yang telah dicetak dibentuk menjadi benda uji sesuai dengan standar masing-masing pengujian.

\section{Pengujian fastening}

Pengujian fastening dilakukan tiga jenis pengujian yaitu pengujian kesesuaian diagonal predrilling terhadap ukuran fastener, pengujian jarak kritis antar dua fastener dan pengujian jarak kritis antara fastener dengan pinggir kayu komposit dan serat daun pandan.

Predrilling adalah pelubangan awal dengan diameter tertentu (di bawah harga diameter gauge fastener) pada tempat dimana fastener akan dipasangkan, dengan tujuan untuk mempermudah dan menghindari kerusakan komposit pada proses fastening. Adapun predrilling dilakukan dengan Banch Dril-ling Machine dengan kecepatan putaran drill 320 rpm.

Papan komposit sesuai dengan standar spesimen astm d7332/d7332m 09 standar dengan ukuran panjang $200 \mathrm{~mm}$, lebar $50 \mathrm{~mm}$, tebal $30 \mathrm{~mm}$.

$30 \mathrm{~mm}$

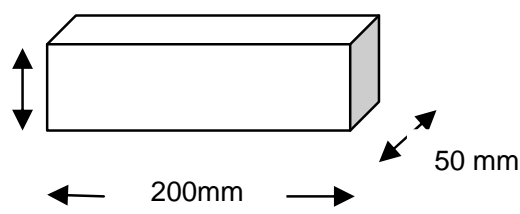

Gambar 3 Dimensi Spesimen Uji Fastening

Pada pengujian akan diperoleh metode fastening, dan ukuran fastener, maka akan dilakukan uji dengan variasi berikut :

1. Pemasangan fastener didahului predrilling $0 ; 1 ; 2 ; 3 ; 3.5 ; 4 ; 4.5 ; 5$ $\mathrm{mm}$, dengan ukuran sekrup sebagai fastener:

Fastener \# 6 ( $\varnothing$ lu $3,51 \mathrm{~mm}, \emptyset$ du 3 $\mathrm{mm}, \mathrm{p} 1,25$ inchi $)$

Fastener \# 8 ( $\varnothing$ lu 4,2 mm, $\emptyset$ du 3,5 $\mathrm{mm}, \mathrm{p} 1,25$ inchi)

Fastener \# 10 ( $\varnothing$ lu 4,82 mm, $\emptyset$ du 4 $\mathrm{mm}, \mathrm{p} 1,25$ inchi)

2. Jarak antara dua sekrup mula - mula diambil $20 \mathrm{~mm}$ dan kemudian berkurang masing-masing $3 \mathrm{~mm}$ sampai diperoleh jarak dua sekrup yang menyebabkan retaknya komposit.
3. Jarak lubang sekrup ke pinggir komposit mula-mula $12 \mathrm{~mm}$ da kemudian berkurang berturutan $2 \mathrm{~mm}$ dimana disesuaikan dengan jari-jari kepala fastener sampai diperoleh jarak yang menyebabkan retaknya komposit.

Adapun ukuran spesimen masingmasing pengujian adalah sebagai berikut :

1. $(200 \times 50 \times 31) \mathrm{mm}^{3}$ untuk pengujian kesesuaian predrilling terhadap fastener.

2. $(125 \times 50 \times 31) \mathrm{mm}^{3}$ untuk pengujian jarak kritis antar dua fastener

3. $(75 \times 50 \times 31) \mathrm{mm}^{3}$ untuk pengujian jarak kritis antara fastener dengan pinggir komposit.

\section{HASIL DAN PEMBAHASAN}

Tabel 1. Hasil Pengujian Fastening jarak kritis antar tepi pada papan komposit dengan resin polyester diperkuat serat pandan wangi

\begin{tabular}{|c|c|c|c|c|c|c|c|c|c|c|}
\hline \multirow{2}{*}{\multicolumn{2}{|c|}{$\begin{array}{c}\begin{array}{c}\text { Fralksi volume } \\
\text { serbuk kayu }\end{array} \\
\text { Fralksi volume } \\
\text { resin polyester }\end{array}$}} & \multicolumn{7}{|c|}{$5 \%$} & \multirow{3}{*}{\multicolumn{2}{|c|}{$\begin{array}{l}\text { Rata-rata } \\
\text { pengujian } \\
\text { fartening }\end{array}$}} \\
\hline & & \multicolumn{3}{|c|}{$75 \%$} & \multicolumn{4}{|c|}{$65 \%$} & & \\
\hline \multicolumn{2}{|c|}{$\begin{array}{c}\text { Fralssi volume } \\
\text { serat }\end{array}$} & \multicolumn{3}{|c|}{$20 \%$} & \multicolumn{4}{|c|}{$30 \%$} & & \\
\hline \multirow{2}{*}{$\begin{array}{l}\text { Panjang } \\
\text { serat }\end{array}$} & \multirow{2}{*}{ Fastenep } & \multirow{2}{*}{ I } & \multirow[t]{2}{*}{ II } & \multirow{2}{*}{ III } & \multirow{2}{*}{ Fastener } & \multirow{2}{*}{ I } & \multirow{2}{*}{ II } & \multirow{2}{*}{ III } & & \\
\hline & & & & & & & & & $20 \%$ & $30 \%$ \\
\hline \multirow{3}{*}{15} & $=6$ & 3.36 & 3.28 & 3.24 & $=6$ & 2.6 & 2.78 & 2.76 & 3.29 & 2.71 \\
\hline & $=8$ & 3.52 & 3.6 & 3.74 & $=8$ & 2.92 & 2.8 & 2.84 & 3.62 & 2.85 \\
\hline & $=10$ & 5.6 & 5.42 & 5.5 & $=10$ & 4.42 & 4.6 & 4.54 & 5.51 & 4.52 \\
\hline \multirow{3}{*}{20} & $=6$ & 3.2 & 3.06 & 3.14 & $\# 6$ & 2.4 & 2.54 & 2.34 & 3.13 & 2.43 \\
\hline & $=8$ & 3.3 & 3.2 & 3.34 & $=8$ & 2.48 & 2.34 & 2.5 & 3.28 & 2.44 \\
\hline & $=10$ & 4.62 & 4.5 & 4.48 & $=10$ & 3.8 & 3.94 & 4 & 4.54 & 3.91 \\
\hline \multirow{3}{*}{30} & $=6$ & 2.4 & 2.14 & \begin{tabular}{|l|}
2.3 \\
\end{tabular} & $\neq 6$ & 1.8 & 1.9 & 1.84 & 2.28 & 1.85 \\
\hline & $=8$ & 2.98 & 2.68 & 2.76 & $=8$ & 1.88 & 1.8 & 1.94 & 2.81 & 1.87 \\
\hline & $\$ 10$ & 3.84 & 3.56 & \begin{tabular}{|l}
3.7 \\
\end{tabular} & $\$ 10$ & 3.04 & 2.96 & 3.18 & 3.7 & 3.06 \\
\hline
\end{tabular}

Tabel 2 Perhitungan To ways Analysis of Variances Uji Fastening (Jarak kritis fastener \#6 antar tepi)

\begin{tabular}{|c|c|c|c|c|c|}
\hline $\begin{array}{l}\text { Sumber } \\
\text { variasi }\end{array}$ & $\begin{array}{l}\text { Jumlah } \\
\text { kuadrat }\end{array}$ & $\begin{array}{c}\text { Derajat } \\
\text { kebebas } \\
\text { an }\end{array}$ & $\begin{array}{l}\text { Rataan } \\
\text { kuadrat }\end{array}$ & $\begin{array}{c}\mathrm{f} \\
\text { hitungan }\end{array}$ & f tabel \\
\hline $\begin{array}{l}\text { panjang } \\
\text { serat }\end{array}$ & 2.956933 & 2 & 1.478467 & 162.6675 & 3.835294 \\
\hline $\begin{array}{l}\text { Fralcsi } \\
\text { volume } \\
\text { serat }\end{array}$ & 1.433689 & 1 & 1.433689 & 157.7408 & 4.747225 \\
\hline $\begin{array}{l}\text { Panjang } \\
\text { erat dan } \\
\text { fraksi } \\
\text { volume } \\
\text { serat }\end{array}$ & 0.056311 & 2 & 0.028156 & 3.0978 & 3.885294 \\
\hline Galat & 0.109067 & 12 & 0.009089 & & \\
\hline Jumlah & 4.556 & 17 & & & \\
\hline
\end{tabular}

Adapun dari nilai rata-rata tabel 2 dapat dgambarkan dengan grafik seperti pada gambar 4. 


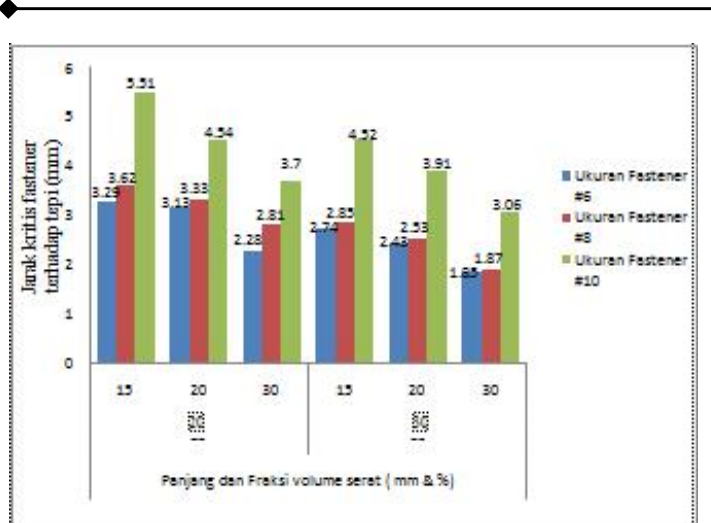

Gambar 4 Grafik rata-rata jarak kritis antar tepi $(\mathrm{mm})$

Dari gambar grafik di atas dapat dilihat bahwa jarak kritis fastener \#6 terhadap panjang serat $15 \mathrm{~mm}$ dengan fraksi volume $20 \%$ ke tepi sebesar $3,29 \mathrm{~mm}$, terlihat pada gambar 5 .

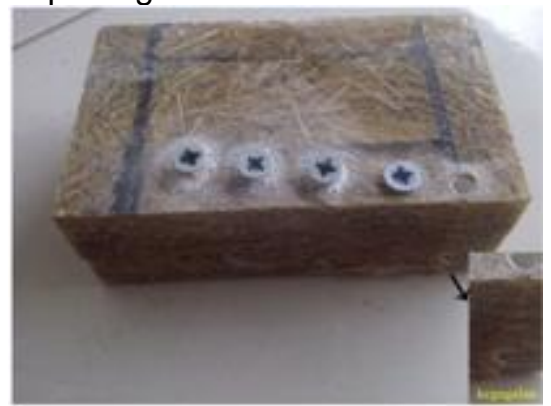

Gambar 5. Fastener \#6 panjang serat 15 $\mathrm{mm}$, fraksi volume $20 \%$, pengulangan ke 3 .

Berbeda dengan fastener \#8, panjang dan fraksi volume serat yang sama memiliki jarak kritis antar tepinya lebih besar dibandingkan fastener \#6 dikarenakan diameter kepala fastener dan ulir yang lebih besar sehingga penetrasi yang diberikan lebih besar dibandingkan pada fastener \#6 yaitu $3,62 \mathrm{~mm}$, begitupun juga pada fastener ukuran \#10 namun lebih tinggi dibandingkan dengan fastener \#6, dan \# 8, sebesar 5,51 $\mathrm{mm}$, semakin besar penetrasi yang diberikan fastener maka semakin besar pula jarak kritis yang dibutuhkan terhadap tepi. Pada panjang serat $20 \mathrm{~mm}$ dengan fraksi volume $20 \%$, memiliki hasil uji dimana pada ukuran fastener \# 6 nilai jarak kritis antar tepi adalah $3,13 \mathrm{~mm}$, adapun pada ukuran fastener \#8 nilai jarak kritis antar tepinya terhadap panjang serta fraksi volume yang sama yaitu $3,33 \mathrm{~mm}$ sebelum terjadinya kegagalan jarak kritis antar tepi pada gambar 6 .

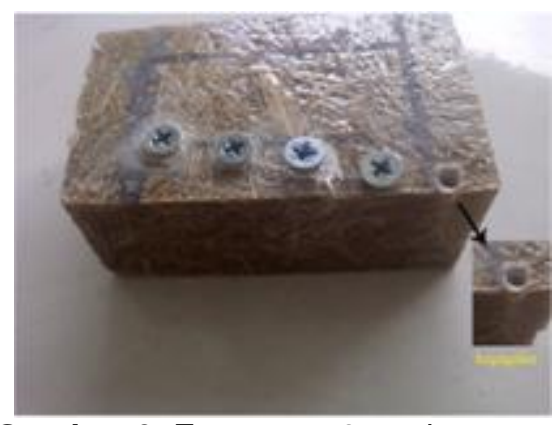

Gambar 6. Fastener \#8 panjang serat 20 $\mathrm{mm}$ dan fraksi volume $20 \%$ pengulangan ke 2

Fastener \#10 dimana panjang dan fraksi volume serat yang sama memiliki nilai 4,54 $\mathrm{mm}$. Penambahan panjang serat sebesar 5 $\mathrm{mm}$ menyebabkan berkurangnya nilai jarak kritis antar tepi pada spesimen yang panjang seratnya $15 \mathrm{~mm}$. Jarak Kritis antar tepi fastener \#6 pada panjang serat $30 \mathrm{~mm}$ dengan fraksi volume $20 \%$ diperoleh 2,28 $\mathrm{mm}$, adapun jarak kritis antar tepi fastener \#8 dimana panjang serat $30 \mathrm{~mm}$ dan fraksi volume serat $20 \%$ yaitu $2,81 \mathrm{~mm}$. Selanjutnya ukuran fastener \#10 didapatkan nilai lebih rendah daripada fraksi volume serat daun pandan $20 \%$ dengan panjang serat $15 \mathrm{~mm}$, dan $20 \mathrm{~mm}$, yang dimana nilai sebesar $3,7 \mathrm{~mm}$. Lebih dari itu didapatkan kegagalan jarak kritis fastener antar tepi yang bisa dilihat pada Gambar 7 dibawah ini

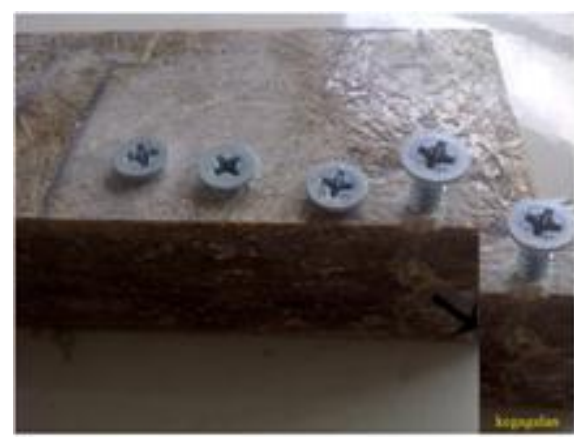

Gambar 7. Fastener \#10 panjang serat 30 $\mathrm{mm}$, fraksi volume $20 \%$, pengulangan ke 1 .

Panjang serat daun pandan wangi 30 $\mathrm{mm}$ mampu mengikat resin polyester lebih baik walau terdapat sedikit void dibandingkan dengan panjang serat $15 \mathrm{~mm}$ dan $20 \mathrm{~mm}$.

Ukuran fastener \#6 terhadap panjang serat $15 \mathrm{~mm}$ dengan fraksi volume $30 \%$ jarak kritis antar tepi yang di dapat adalah $2,74 \mathrm{~mm}$ adapun kegagalan yang terjadi pada fastener \# 6 setelah pengukuran diatas dapat dilihat seperti gambar 8 . 


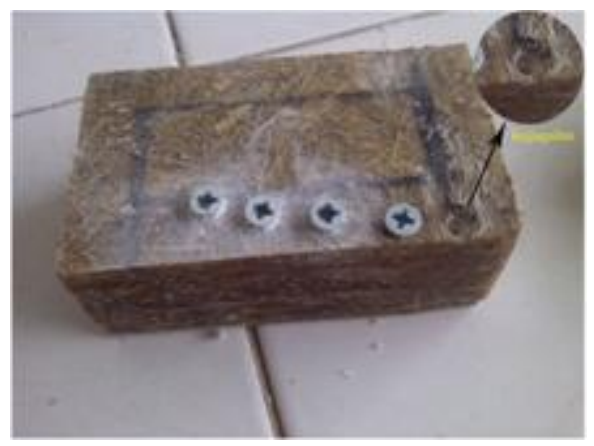

Gambar 8. Fastener \#6 panjang serat 15 $\mathrm{mm}$, fraksi volume $30 \%$, pengulangan ke 1

Fastener \#8 diperoleh hasil 2,85 $\mathrm{mm}$ dan ukuran fastener \#10 yaitu $4,52 \mathrm{~mm}$. Berbeda sebelumnya nilai pada panjang $15 \mathrm{~mm}$ dan fraksi volume serat pandan wangi sebesar $20 \%$, dikarenakan adanya penambahan fraksi volume serat pandan wangi sebesar $10 \%$ menjadi $30 \%$ yang membuat kekuatan papan komposit bertambah. Adapun nilai yang terdapat pada ukuran fastener \# 6 dengan panjang serat $20 \mathrm{~mm}$ dengan fraksi volume $30 \%$ lebih rendah dibandingkan saat nilai pada panjang serat 20 dimana fraksi volumenya $20 \%$ sebesar $2,34 \mathrm{~mm}$, begitupun juga pada fastener \# 8 adalah $2,53 \mathrm{~mm}$, dilihat pada gambar 9 .

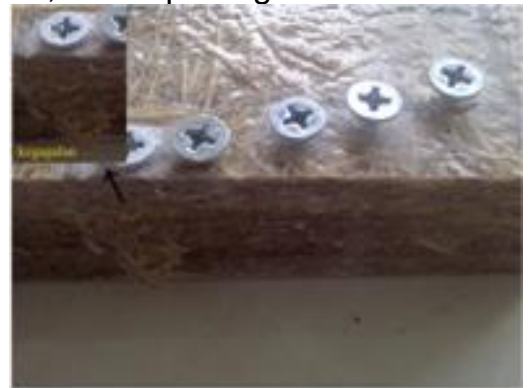

Gambar 9. Fastener \#8 panjang serat 20 $\mathrm{mm}$, fraksi volume $30 \%$, pengulangan ke 1 Fastener \# 10 yaitu $3,91 \mathrm{~mm}$, penambahan panjang serat $5 \mathrm{~mm}$ dan fraksi volume serat sebesar $10 \%$ menyebabkan jarak kritis fastener antar tepi pada papan komposit semakin dekat. Pada panjang serat $30 \mathrm{~mm}$ dengan fraksi volume $30 \%$ memiliki nilai paling rendah dari yang laennya baek masing-masing ukuran fastener yaitu \#6 $(1,85 \mathrm{~mm})$, \#8 $(1,87 \mathrm{~mm})$ dan \# 10 ( 3,06 mm ) dikarenakan panjang dan fraksi volume serat yang berfungsi sebagai berpengaruh nyata mampu menahan penetrasi dari fastener lebih baik dibandingkan dengan fraksi volume sebesar $20 \%$ dapat dilihat pada gambar 10 .

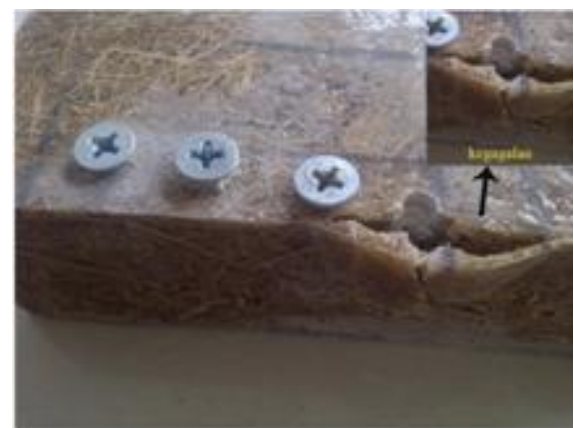

Gambar 10. Fastener \#8 panjang serat $20 \mathrm{~mm}$, fraksi volume $20 \%$, pengulangan ke

\section{KESIMPULAN}

Dari penelitian yang telah dilakukan maka dapat disimpulkan bahwa pada pengujian fastening papan komposit serat pandan wangi dan limbah kayu dengan resin polyester dipengaruhi oleh panjang serat dan fraksi volume serat pandan wangi.

1. Metode pemasangan fastener terhadap papan komposit melalui proses predrilling dengan diameter prediriling mendekati diameter ulir fastener. Fasterner \#6, \#8, \#10 adalah $3,5 \mathrm{~mm}, 4$ $\mathrm{mm}, 4,5 \mathrm{~mm}$

2. Jarak kritis antara fastener satu dengan fastener yang lain tidak ada, melainkan jarak minimal tergantung pada kepala fastener tersebut. Jarak minimal antar fastener \#6, \#8, \#10 adalah $6 \mathrm{~mm}, 8$ $\mathrm{mm}$, dan $10 \mathrm{~mm}$.

3. Pada jarak kritis fastener antar tepi, panjang dan fraksi volume serat pandan wangi memiliki pengaruh yang nyata hal ini dapat dilihat perbedaan nilai yang sangat besar pada fastener \#6 dengan panjang serat $15 \mathrm{~mm}$ dan fraksi volume $20 \%$ dengan fastener \#6 panjang serat $15 \mathrm{~mm}$ dan fraksi volume $30 \%$ sebesar $3,29 \mathrm{~mm}$ dan 2,74 antar tepi.

4. Nilai koefisien abrasi pada komposit pandan wangi dengan fraksi volume serat $20 \%$ lebih besar dari fraksi volume serat $30 \%$. Demikian juga semakin kecil panjang serat nilai koefisien abrasi yang terjadi semakin besar. nilai koefisien abrasi tertinggi terjadi pada fraksi volume serat $20 \%$ dan panjang serat 15 $\mathrm{mm}$ yaitu 0,000724 , sedangkan nilai koefisien abrasi terendah terjadi pada fraksi volume $30 \%$ dan panjang serat $30 \mathrm{~mm}$ yaitu $2,77 \mathrm{E}-05$ 


\section{DAFTAR PUSTAKA}

[1] Hotman, A., M, 2013. "Karakteristik Kekuatan Bending Dan Kekuatan Tarik Komposit Serat Alam Dengan Resin Epoxy" Universitas Mataram

[2] Sulistyowati,D., E, dkk 2012. "Pengaruh Panjang Serat dan Fraksi Volume Terhadap Kekuatan Impact dan Bending Material Komposit Polyester-Fiber Glass dan PolyesterPandan Wangi" Dinamika Teknik Mesin / vol. 2/No. 1 halaman : 15

[3] Catur, D., C., dkk ,2009. Fastening Sandwich Composite Polyester
Methods Reinforced Plants FiberIndustri Waste with Honeycomb Core of used Paper. Dinamika Teknik Sipil / vol. 12/No. 1 halaman :11

[4] Maulida, 2006, Perbandingan Kekuatan Tarik Komposit Polipropilena Dengan Pengisi Serat Pandan dan Serat Daun Pisang, Jurnal Teknologi Proses, Universitas Sumatra Utara.

[5] ASTM standard C33, 2003. "Specification for Concrete Aggregates," ASTM International, West Conshohocken, PA, 2003, DOI : 10.1520/C0033-03 